\title{
The effect of a hindered amine light stabilizer on the aging behavior of moisture-curable polyurethane as a cultural relics consolidant
}

\author{
Xing Zhao(1), 2), Liqin Wang(1), 2), *), Lang Guo ${ }^{1)}$, Yanni Ma ${ }^{1)}$, Ziming Wang ${ }^{2)}$, Qing $\mathrm{Niu}^{3)}$ \\ DOI: dx.doi.org/10.14314/polimery.2020.4.6
}

\begin{abstract}
This paper aims to study the effect of a hindered amine light stabilizer (HALS 770), on the aging behavior of moisture-curable polyurethane (MCPU). MCPU is specifically developed by ourselves for the reinforcement of fragile organic cultural relics in high-humidity environments, but its aging resistance is insufficient. To improve the aging resistance of MCPU, HALS 770 was used to prepare a modified MCPU (MMCPU). A colorimeter, an infrared spectrometer and a thermal analyzer were used to characterize the color and structure changes of MCPU and MMCPU during aging and to determine their aging kinetics. The results show that the activation energy for the thermal decomposition increased from $91-109 \mathrm{~kJ} / \mathrm{mol}$ to $135-151 \mathrm{~kJ} / \mathrm{mol}$. When the color change is used as the indicator for aging, the lifetime of MMCPU under UV aging is 133\% longer than that of MCPU, the lifetime of MMCPU under thermal aging at $293 \mathrm{~K}$ is 41.3 times that of MCPU. The addition of HALS 770 to MCPU significantly inhibits the aging behavior.
\end{abstract}

Keywords: moisture-curable polyurethane, hindered amine light stabilizer HALS 770, consolidant, cultural relics, aging, light stabilizer.

\section{Wpływ aminowego stabilizatora światła z zawadą przestrzenną na starzenie utwardzanego wilgocią poliuretanu stosowanego jako konsolidator zabytków}

\begin{abstract}
Streszczenie: Zbadano wpływ dodatku aminowego stabilizatora światła z zawadą przestrzenną (HALS 770) na starzenie się poliuretanu utwardzanego w kontakcie z wilgocią (MCPU). MCPU opracowano specjalnie do wzmacniania delikatnych organicznych zabytków kultury w środowiskach o dużej wilgotności, jednak jego odporność na starzenie jest niewystarczająca. W celu zwiększenia odporności na starzenie MCPU modyfikowano (otrzymano MMCPU) dodatkiem aminowego stabilizatora światła $\mathrm{z}$ zawadą przestrzenną (HALS 770). Zmiany koloru, przyjęte jako wskaźnik starzenia, i struktury MCPU oraz kinetykę procesu oceniano z wykorzystaniem kolorymetru, spektrometru podczerwieni i analizatora termicznego. Wyniki wskazują, że dodatek HALS $770 \mathrm{w}$ istotnym stopniu hamuje procesy starzenia MCPU - stwierdzono zwiększenie energii aktywacji rozkładu termicznego, z 91-109 kJ/mol MCPU do $135-151 \mathrm{~kJ} / \mathrm{mol}$ - MMCPU. MMCPU w procesie starzenia UV był o 133\% stabilniejszy niż MCPU i 41,3 razy bardziej odporny na starzenie termiczne w $293 \mathrm{~K}$.

Słowa kluczowe: poliuretan utwardzany w kontakcie z wilgocią, aminowy stabilizator światła HALS 770, konsolidator, relikty kulturowe, starzenie, stabilizator światła.
\end{abstract}

Certain archeological sites, such as tombs and grottos, are usually very humid, and the relative humidity is generally above $90 \%$. After an extended burial, the status of organic cultural relics is extremely poor. Such artifacts would easily break with a single touch or scatter on one blow. Sometimes, the transfer of relics from tombs is impossible without damaging them. Therefore, these fragile cultural relics are usually consolidated with reinforcement materials before they are taken out and transferred to museums. The commonly used materials for

1) Northwest University, Key Laboratory of Cultural Heritage Research and Conservation, Ministry of Education, 229 Taibai North Road, Xi'an, Shaanxi Province, P.R. China.

2) Northwest University, School of Cultural Heritage, 229 Taibai North Road, Xi'an, Shaanxi Province, P.R. China.

3) Xi'an Cultural Heritage Promotion Centre, 375 East Street, Xi'an, Shaanxi Province, P.R. China.

*) Author for correspondence: wangliqin@nwu.edu.cn 
conservation of cultural relics include acrylic resin [1], poly(vinyl butyral) [2,3], organic silicon [4] and epoxy resin [5]. However, these materials are mainly used under normal atmospheric humidity conditions. In highhumidity environments, their use commonly results in a series of problems, such as a difficulty in curing, failure to solidify, whitening after solidification, and poor compatibility with organic cultural relics. Moisture-curable polyurethane is a material specially developed to address these problems in the reinforcement and conservation of fragile organic cultural relics in high-humidity environments [6]. The consolidant is colorless and transparent, but its aging resistance is insufficient.

Commonly used stabilizers for polymer materials include ultraviolet absorbers (UVA) [7], HALS (hindered amine light stabilizer) [8], and light shielding agents [9]. For the conservation of cultural relics, UVA is typically used to reduce the aging of protective materials [10]. However, HALS is rarely used for this purpose. HALS 770 (Tinuvin 770) is a hindered amine light stabilizer with a significant inhibitory effect against the aging of polymers [11]. This study used HALS 770 to modify the selfsynthesized MCPU (moisture-curable polyurethane) to yield a modified MCPU (MMCPU) and studied the effect of HALS 770 on the aging behavior of polyurethane, providing a reference for studies on the stability of materials employed for the conservation of cultural relics.

\section{EXPERIMENTAL PART}

\section{Materials}

Isophorone diisocyanate (IPDI, 99\%), and poly(ethylene glycol) [is also known as poly(ethylene oxide) (PEO)] 600 (PEG600) were purchased from Aladdin company. Dibutyltin dilaurate (DBTDL, AR) was produced by Chengdu Kelong.

Bis (2,2,6,6-tetramethyl-4-piperidinyl) sebacate (98\%) (HALS 770) was obtained from Dongguan Wenhua.

Ethyl acetate (AR) was produced by Tianjin Kemiou Chemical Reagent Co., Ltd.

\section{Preparation of MCPU and MMCPU solutions}

MCPU was synthesized with a $1.11: 1: 0.01$ mass ratio of IPDI/PEG600/DBTDL. The reaction took place at $60^{\circ} \mathrm{C}$ for $3 \mathrm{~h}$ until the MCPU prepolymer was obtained. And then the prepolymer was dissolved in ethyl acetate to get a 20 wt \% MCPU solution.

HALS 770 ( $1 \mathrm{wt} \%$ of MCPU prepolymer) was added to a MCPU solution to get a MMCPU solution.

\section{Preparation of the MCPU and MMCPU films}

$3 \mathrm{~cm}^{3}$ of MCPU solution or MMCPU solution was dropped on a slide and placed in the environments with relative humidity levels about $99 \%$, respectively. The films were cured for $24 \mathrm{~h}$, and then the colorimetric values and Fourier transform infrared (FT-IR) spectra were measured.

\section{Methods of aging}

Each sample film was placed $5 \mathrm{~cm}$ below a $254 \mathrm{~nm}$ UV lamp (Zijing, Tianjin China) and exposed to the UV irradiance $\left(245 \mu \mathrm{W} / \mathrm{cm}^{2}\right.$ on average) for UV aging and in an oven (DHG-9035A, Shanghai, China) for thermal aging at $373 \mathrm{~K}$ or $393 \mathrm{~K}$, respectively.

\section{Methods of testing}

\section{Colorimetric measurement}

The colorimetric values of the thin films were measured using a Kangguang SC-80C colorimeter (Beijing, China) with a D65 standard light source and an observation angle of $10^{\circ}$. Each sample film was measured on the top of the standard whiteboard of the colorimeter.

\section{Infrared spectroscopy analysis}

FT-IR spectra of the samples were acquired using the attenuated total reflectance (ATR) accessory of a LUMOS FTIR microscope (Bruker, Germany).

\section{RESULTS AND DISCUSSION}

\section{Results of UV aging}

Light is one of the most important factors affecting the aging of materials for the conservation of cultural relics. In this experiment, $254 \mathrm{~nm}$ UV radiation was selected for accelerated aging. During UV aging, the cured film gradually became yellow, but no other aging phenomena, such as bubble formation, brittleness, and tackiness, occurred. Meanwhile, considering the selection of materials for the conservation of cultural relics, the principle of "not altering the original appearance of cultural relics" should be followed; therefore, color was chosen as the evaluation indicator for aging. The chromaticity was described using the CIELab (1976) system. The color difference is expressed as $\Delta E[12,13]$ :

$$
\Delta E=\left[\Delta L^{* 2}+\Delta a^{* 2}+\Delta b^{* 2}\right]^{1 / 2}
$$

where: $\Delta E, \Delta L^{*}, \Delta a^{*}, \Delta b^{*}$ indicate the changes of the color, the $L^{*}$ value, the $a^{*}$ value and the $b^{*}$ value after and before aging respectively. $L^{*}$ is used to describe the lightness of the color ( 0 means black, while 100 means white), the $a^{*}$ parameter indicates the green or red axis (negative means green, while positive means red), and the $b^{*}$ parameter is used to describe differences in the blue or yellow axis (negative means blue, while positive means yellow). 
a)

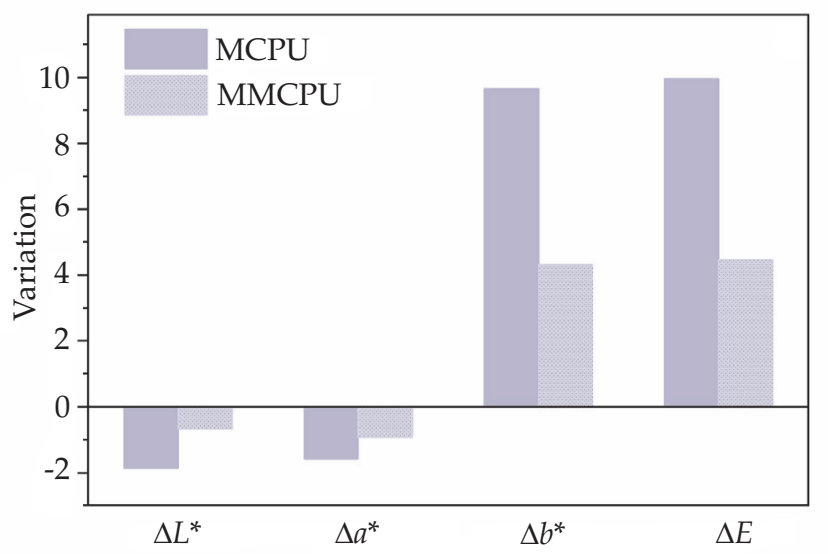

b)

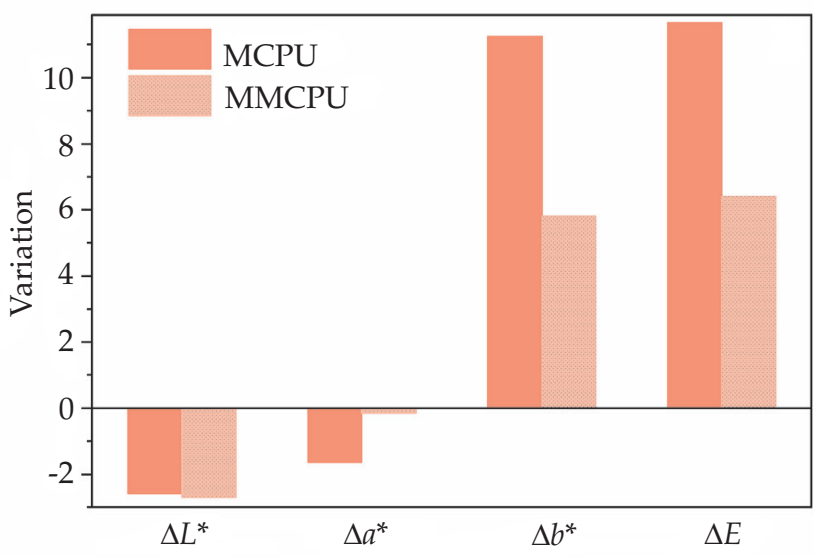

Fig. 1. Changes in the colorimetric values of the MCPU and MMCPU films attributed to aging: a) UV aging for $72 \mathrm{~h}$, b) thermal aging for $21 \mathrm{~h}$ at $120^{\circ} \mathrm{C}$

When $\Delta E$ exceeds 6, the color changes significantly. The experimental results show that during the aging process, $\Delta L^{*}$ and $\Delta a^{*}$ did not change significantly, while $\Delta b^{*}$ was substantially increased; in addition, the $\Delta b^{*}$ value exceeded $90 \%$ of $\Delta E$ value basically (Fig.1). Therefore, $\Delta b^{*}=6$ was used as the lifetime endpoint in this study.

The $\Delta b^{*}$ values of MCPU and MMCPU present linear relationships with time for UV aging (Fig. 2). The slope of the fitted line for the MCPU samples is $0.1338 / \mathrm{h}$, and the lifetime is $45 \mathrm{~h}$, whereas the slope of the fitted line for the MMCPU samples is $0.0575 / \mathrm{h}$, and the lifetime is $104 \mathrm{~h}$. Therefore, after adding HALS 770, the aging rate of MMCPU is reduced by $57 \%$, and the lifetime value of MMCPU is $231 \%$ of the original lifetime.

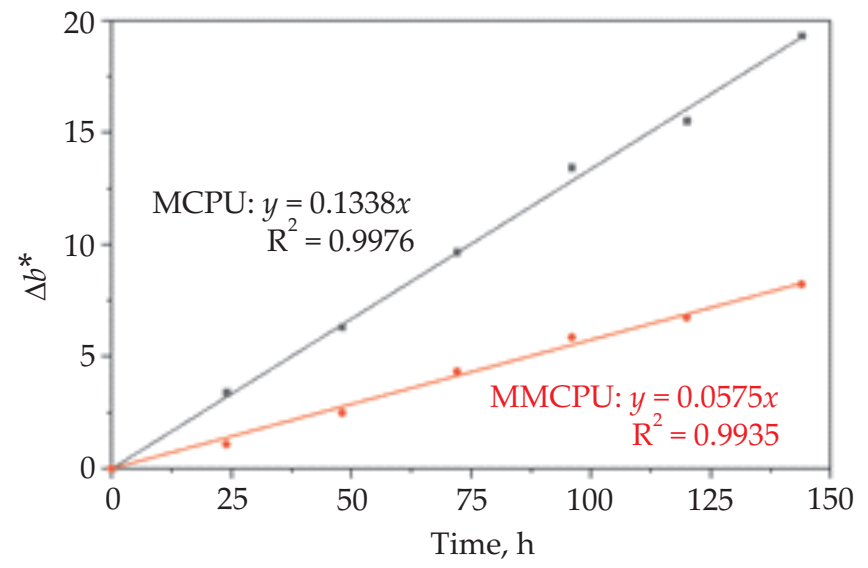

Fig. 2. Relationships between $\Delta b^{*}$ of the MCPU and MMCPU films and time during UV aging

\section{Results of thermal aging}

Thermal aging is inevitable in the preservation of cultural relics. When the ambient temperature rises, the thermal motion of molecules inside a material is exacerbated due to the influence of the temperature increase in the material. The reactant molecules acquire more energy, which can even lead to chain scission. During the thermal aging process, the MCPU films gradually turned yellow, but there were no significant changes in their mechanical properties. The $\Delta b^{*}$ values of the MCPU and MMCPU films thermally aged at $373 \mathrm{~K}$ and $393 \mathrm{~K}$ are shown in Fig. 3. When $\Delta b^{*}=6$ is used as the lifetime endpoint, MCPU exhibits a lifetime of $39 \mathrm{~h}$ at $373 \mathrm{~K}$ and a lifetime of $10 \mathrm{~h}$ at $393 \mathrm{~K}$, whereas MMCPU presents a lifetime of $141 \mathrm{~h}$ at $373 \mathrm{~K}$ and a lifetime of $22 \mathrm{~h}$ at $393 \mathrm{~K}$, which are 3.6 and 2.2 times the values obtained before modification, respectively.

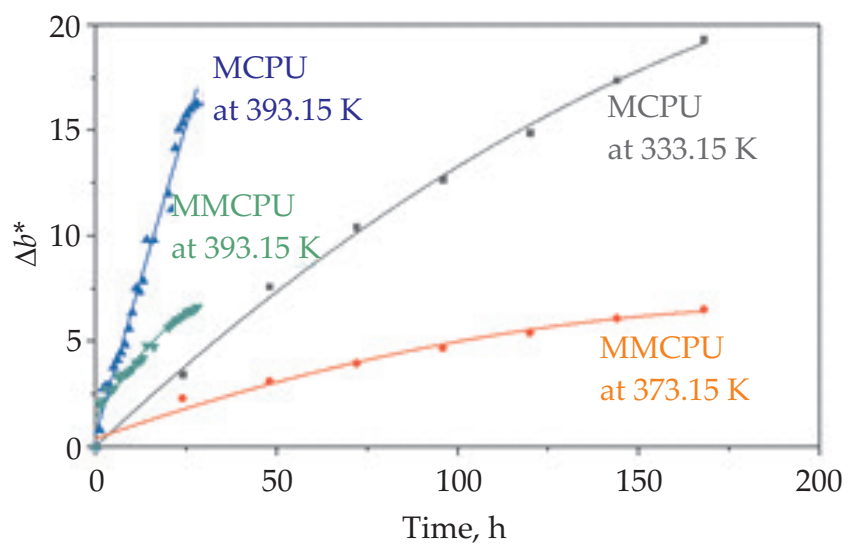

Fig. 3. Relationships between $\Delta b^{*}$ of the MCPU and MMCPU films and time obtained during thermal aging

Dakin proposed an empirical equation for thermal aging:

$$
\lg \tau=a^{\prime} / T+b^{\prime}
$$

where: $T$ is the ambient temperature $(\mathrm{K}), \tau$ is the expected lifetime (h) in the environment at temperature $T$, and $a^{\prime}$ and $b^{\prime}$ are constants.

By introducing the lifetimes of the samples at $373 \mathrm{~K}$ and $393 \mathrm{~K}$ into the Dakin equation, the lifetime equations for MCPU [Eq. (3)] and MMCPU [Eq.( 4)] are obtained: 


$$
\begin{aligned}
& \lg \tau=4479.1154 / T-10.4138 \\
& \lg \tau=5895.7752 / T-13.6503
\end{aligned}
$$

Consequently, when the temperature was lower, the lifetimes of MCPU and MMCPU were longer, and as the temperature increased, the lifetimes of MCPU and MMCPU decreased sharply; when the temperature was higher, the lifetimes of MCPU and MMCPU were shorter, and the changes in lifetimes with temperature became shallower (Fig. 4). In the $293 \mathrm{~K}$ (room temperature) environment, the expected lifetimes of MCPU and MMCPU are $8 \mathrm{y}$ and $330 \mathrm{y}$, respectively. According to the stability classification of materials for the conservation of cultural relics (Table 1) [14], MCPU and MMCPU can be classified as class $\mathrm{C}$ and excellent materials, respectively. The lifetime of the MMCPU is 41.3 times that of MCPU, indicating that the modification greatly improves the thermal stability of MCPU.

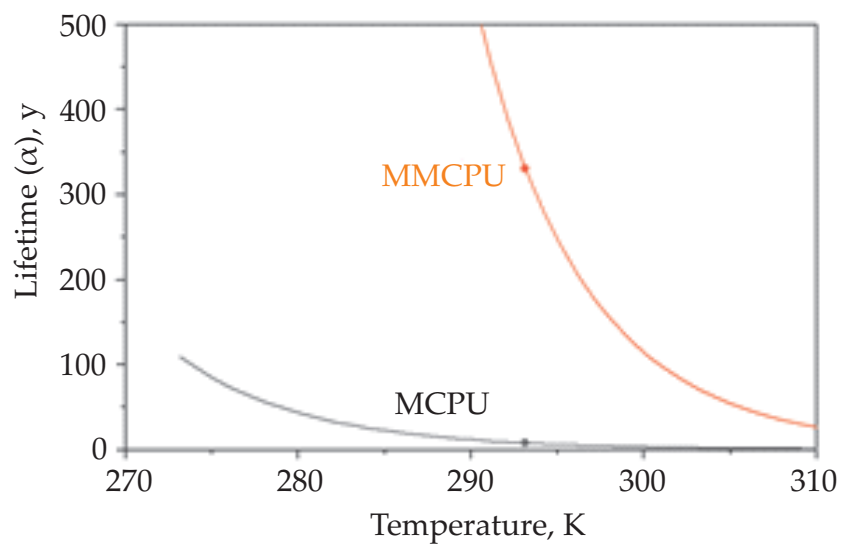

Fig. 4. Relationships between the expected lifetime and temperature for MCPU and MMCPU when using color as the indicator

$\mathrm{T}$ a b 1 e 1. Classification of materials for the conservation of

\begin{tabular}{|c|c|c|}
\hline $\begin{array}{l}\text { Lifetime } \\
\text { year }\end{array}$ & Class & Remarks \\
\hline $0-20$ & $\mathrm{C}$ & Stability needs to be improved \\
\hline $20-100$ & $\mathrm{~B}$ & $\begin{array}{c}\text { Can be selectively applied for } \\
\text { the conservation of cultural } \\
\text { relics }\end{array}$ \\
\hline $100-200$ & A & $\begin{array}{l}\text { Can be applied for the } \\
\text { conservation of cultural relics }\end{array}$ \\
\hline$>200$ & $\begin{array}{l}\text { Excellent } \\
\text { materials }\end{array}$ & $\begin{array}{l}\text { Stable materials that are } \\
\text { preferred for the conservation } \\
\text { of cultural relics }\end{array}$ \\
\hline
\end{tabular}
cultural relics according to their stability

\section{Aging kinetics}

Thermal analysis is an effective means to measure the thermal stability of solid materials and can be used to study the aging kinetics of materials. According to the Coats-Redfern method [15], when $-\lg \left[-\lg (1-\alpha) \cdot T^{-2}\right]$ is linearly related to $1 / T$, the reaction is first order, in which $\alpha$ is the conversion rate and $T$ is the thermodynamic temperature.

In Fig. 5, the data points $\left\{-\lg \left[-\lg (1-\alpha) \cdot T^{-2}\right], 1 / T\right\}$ for different heating rates are fitted by straight lines $(R>0.99)$. These plots indicate that the reaction orders for the thermal decompositions of MCPU and MMCPU are unrelated to the heating rate; the thermal decomposition reactions at the heating rates of 5,10 , and $15 \mathrm{~K} / \mathrm{min}$ are all first-order reactions.
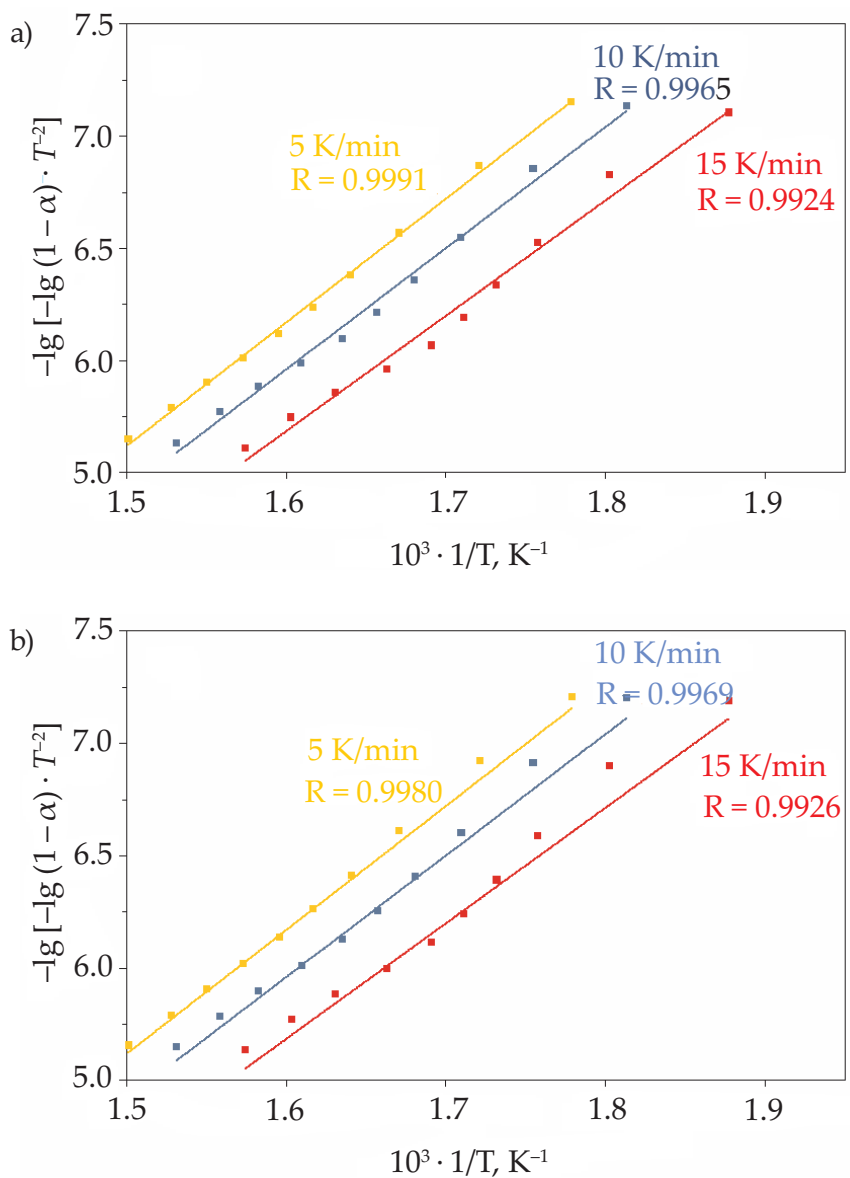

Fig. 5. Kinetic plots of the thermal decompositions of MCPU and MMCPU obtained using the Coats-Redfern method: a) MCPU, b) MMCPU

Based on the Arrhenius equation, the transformation of the reaction kinetics equation using Doyle's approximation yields the following equation [16]:

$$
\lg \beta=-\frac{0.4567 E_{a}}{R T}+\lg \left[-A E_{a} / R \ln (1-\alpha)\right]-2.315
$$

where: $\alpha$ is the conversion rate, $T$ is the thermodynamic temperature $(\mathrm{K}), \beta$ is the heating rate $(\mathrm{K} / \mathrm{min}), A$ is the pre-exponential factor $\left(\mathrm{min}^{-1}\right), E_{a}$ is the activation energy $(\mathrm{J} / \mathrm{mol})$, and $R$ is the ideal gas constant. The plot of $\lg \beta$ vs. $1 / T$ is a straight line at a fixed conversion rate; thus, the activation energy $E_{a}$ can be obtained from the slope, and the pre-exponential factor $A$ can be derived from the intercept. The activation energy of the thermal decomposition of MCPU is $91-109 \mathrm{~kJ} / \mathrm{mol}$, and that of MMCPU is $135-151 \mathrm{~kJ} / \mathrm{mol}$ (Fig. 6), which indicates that the activation 


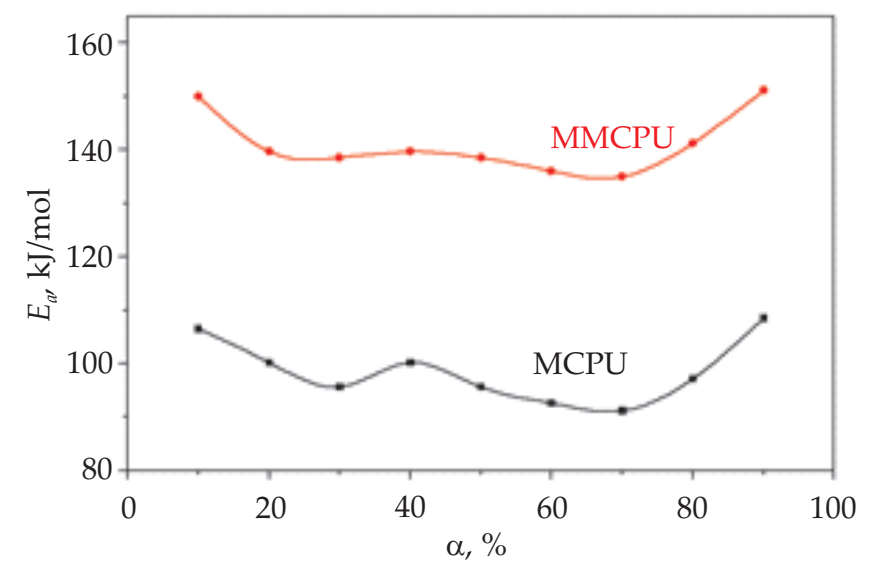

Fig. 6. Activation energies for MCPU and MMCPU at different conversion rates

energy of MCPU is approximately $40 \%$ higher after the addition of HALS 770 (MMCPU).

\section{Mechanisms for the aging of MCPU and stabilization of MCPU by HALS 770}

The changes in the FT-IR spectra of MCPU during UV aging and thermal aging are shown in Fig. 7. The peaks at $1110 \mathrm{~cm}^{-1}$ and $1245 \mathrm{~cm}^{-1}$ are the characteristic peaks of the ether bond in the soft segment [17], the peak at $1556 \mathrm{~cm}^{-1}$ is attributed to C-N [18], the peak at $1653 \mathrm{~cm}^{-1}$ is the characteristic peak of the carbonyl group in urea bonds [19], the peak at $1718 \mathrm{~cm}^{-1}$ is the due to the carbonyl group in urethane bonds [20], the peak at $2906 \mathrm{~cm}^{-1}$ is typical of the methylene group [21], and the peak at $3310 \mathrm{~cm}^{-1}$ is assigned to N-H [22]. The FT-IR spectra of MCPU during UV aging show that the intensities of the peaks at $1110 \mathrm{~cm}^{-1}, 1245 \mathrm{~cm}^{-1}, 1556 \mathrm{~cm}^{-1}$, and $2906 \mathrm{~cm}^{-1}$ decreased, while the intensity of the peak at $3310 \mathrm{~cm}^{-1}$ increased, indicating a reduction in the concentrations of ether, $\mathrm{C}-\mathrm{N}$, and methylene groups and an increase in the N-H concentration. This result is a consequence of ether bonds being easily oxidized under UV light [23]. Furthermore, the methylene groups that were attached to ether bonds [23] or N-H [24] are also easily oxidized under UV light, leading to the decrease in the methylene group concentration with the aging process; in particular, the methylene groups at the $\alpha$ position of the $\mathrm{N}-\mathrm{H}$ can be oxidized to generate hydroperoxide radicals, which further break the $\mathrm{C}-\mathrm{N}$ bonds to form $-\mathrm{NH}_{2}$ [25]. The main difference between the FT-IR spectra of MCPU obtained during thermal aging and those during UV aging is that in the former: the characteristic peak of the carbonyl group in urea bonds at $1653 \mathrm{~cm}^{-1}$ and that of N-H at $3310 \mathrm{~cm}^{-1}$ decreased, while the characteristic peak of the carbonyl group in urethane bonds at $1718 \mathrm{~cm}^{-1}$ increased, indicating the formation of new urethane bonds and the reduction in $\mathrm{N}-\mathrm{H}$ and urea bonds concentrations during thermal aging. These new carbamates were possibly formed by the reactions between isocyanates, from the decomposition of urea bonds [26], and the hydroxyl groups from
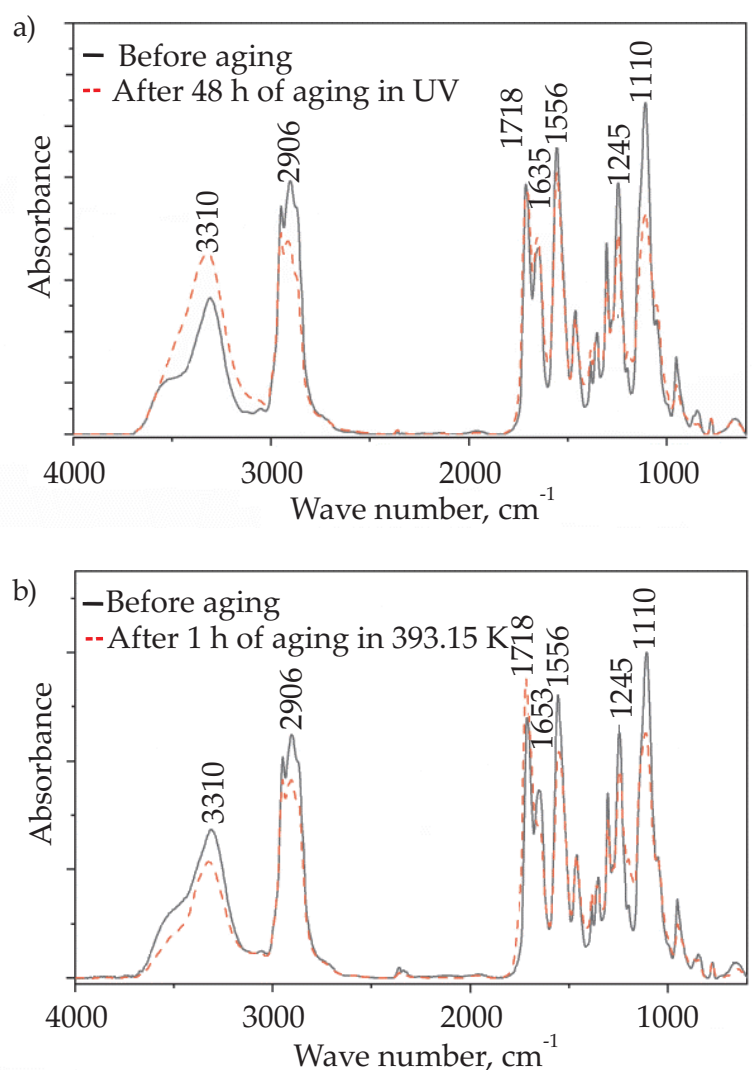

Fig. 7. FT-IR spectra of MCPU before and after aging: a) during UV aging, b) during thermal aging

the aging of ether bonds and methylene groups [23]. The reduction in the $\mathrm{N}-\mathrm{H}$ concentration might have been due to the oxidation or volatilization of small molecules [27].

The alicyclic amines in HALS 770 [Formula (I)] can be converted into free nitroxyl radicals, with regenerative properties. Free nitroxyl radicals possess a stable structure and can effectively capture the free alkoxyl radicals and free alkyl radicals, generated during the aging process of polymers, to form the corresponding esters. These esters react with free radicals in the material to regenerate free nitroxyl radicals and form organic molecular chains, thus consuming abundant activated free radicals and preventing the aging process. The stabilization mechanism [28] is shown in Scheme A. R, R; RO; and ROO- represent organic polymers, free alkyl radicals, free alkoxyl<smiles>CC1(C)CC(OC(=O)CCCCCCCCC(=O)OC2CC(C)(C)NC(C)(C)C2)CC(C)(C)N1</smiles>

Formula (I) 


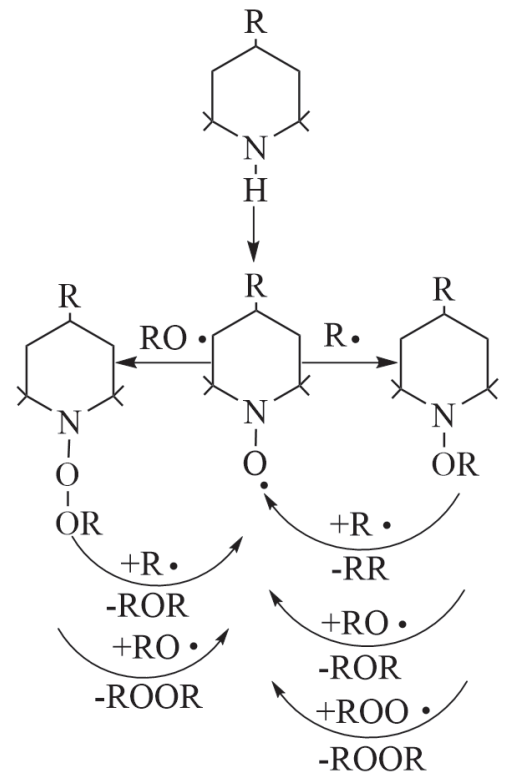

Scheme A

radicals, and free peroxyl radicals, respectively. HALS 770 also reacts with the hydroperoxides produced in the aging process of MCPU and converts them to stable alcohols and ketones. Meanwhile, the generated free nitroxyl radicals further participate in reactions to capture free radicals. This action is the reason why the expected lifetime and stability of MMCPU increases greatly after the HALS 770 modification.

\section{CONCLUSIONS}

During UV and thermal aging processes, the ether bonds of MCPU broke, and the samples gradually turned yellow. After modification with HALS 770, the activation energy for the thermal decomposition of MMCPU became $135-151 \mathrm{~kJ} / \mathrm{mol}$, which is approximately $40 \%$ higher than that of MCPU. When $\Delta b^{*}=6$ was used as the lifetime endpoint, the lifetime of MMCPU during UV aging was $104 \mathrm{~h}$, which represents $231 \%$ of the value for the unmodified MCPU ( $45 \mathrm{~h}$ ), whereas the lifetime of MMCPU during thermal aging at $373 \mathrm{~K}$ and $393 \mathrm{~K}$ are 3.6 and 2.2 times that of the unmodified MCPU. The expected lifetime of MMCPU in the 293K (room temperature) environment was found to be $330 \mathrm{y}$, which is 41.3 times that $(8 \mathrm{y})$ of the unmodified MCPU. The alicyclic amines in the HALS 770 molecules are converted to free nitroxyl radicals that can be regenerated. The free nitroxyl radicals can effectively capture the free radicals generated during the aging of MCPU and prevent the process from proceeding, thereby stabilizing MCPU. This study shows that HALS 770 significantly inhibits the aging behavior of MCPU, providing a reference on the antiaging of materials for the conservation of cultural relics.

In the future, studies on the aging of MCPU under natural conditions and inside cultural relics will be conducted.

\section{ACKNOWLEDGMENTS}

This work was financially supported by the Key Research and Development Plan of Shaanxi Province [2019ZDLSF07-05].

\section{REFERENCES}

[1] Muhcu D., Terzi E., Kartal S., Yoshimura T.: Journal of Forestry Research 2016, 28, 381.

http://dx.doi.org/10.1007/s11676-016-0287-1

[2] France C.A.M., Giaccai J.A., Doney C.R.: American Journal of Physical Anthropology 2015, 157, 330. http://dx.doi.org/10.1002/ajpa.22697

[3] France C.A.M., Giaccai J.A., Cano N.: Journal of Archaeological Science 2011, 38, 3387. http://dx.doi.org/10.1016/j.jas.2011.07.024

[4] Xu F., Wang C., Li D. et al.: Progress in Organic Coatings 2015, 81, 58. http://dx.doi.org/10.1016/j.porgcoat.2014.12.017

[5] Sideridou I., Vouvoudi E., Papadopoulos G.: Journal of Cultural Heritage 2015, 18, 279. http://dx.doi.org/10.1016/j.culher.2015.09.005

[6] Zhao X., Wang L. Q., Bian S. et al.: Chemical Reagents 2017, 39, 699.

[7] Hu G., Sun Y., Xie Y. et al.:. ACS Applied Materials and Interfaces 2019, 11, 6634.

http://dx.doi.org/10.1021/acsami.8b20138

[8] Nguyen T.V., Le X.H., Dao P.H. et al.: Progress in Organic Coatings 2018, 124, 137.

http://dx.doi.org/10.1016/j.porgcoat.2018.08.013

[9] Puri A., Kaur A., Raza K. et al.: Journal of Drug Delivery Science and Technology 2017, 37, 1. http://dx.doi.org/10.1016/j.jddst.2016.09.010

[10] Yang L., Wang L.Q., Huang J.H., Tang L.Q.: Sciences of Conservation and Archaeology 2010, 22, 32.

[11] Slouf M., Michálková D., Gajdošová V. et al.: Polymer Degradation and Stability 2019, 166, 307.

http://dx.doi.org/10.1016/j.polymdegradstab.2019.06.013

[12] Zhao X., Wang L., Zhao X. et al.: Journal of Adhesion Science and Technology 2018, 32, 2421. http://dx.doi.org/10.1080/01694243.2018.1481494

[13] Chorobiński M., Skowronski L., Bielinski M.: Polimery 2019, 64, 690. http://dx.doi.org/10.14314/polimery.2019.10.6

[14] Feller R.L.: "Accelerated aging photochemical and thermal aspects", Getty Conservation Institute, Los Angeles 1994, p. 5.

[15] Coats A.W., Redfern J.P.: Nature 1965, 201, 68. http://dx.doi.org/10.1038/201068a0

[16] Yao F., Wu Q., Lei Y. et al.: Polymer Degradation and Stability 2008, 93, 90.

http://dx.doi.org/10.1016/j.polymdegradstab.2007.10.012

[17] Xu J., Zhang C., Zhou Y. et al.: Advanced Materials Research 2012, 599, 36.

http://dx.doi.org/10.4028/www.scientific.net/ AMR.599.36 
[18] Wang A., Wu L., Sun Y. et al.: Advanced Materials Research 2011, 201-203, 2862.

http://dx.doi.org/10.4028/www.scientific.net/ AMR.201-203.2862

[19] Wu L.Z., Wu H., Xu X.D., Yang J.S.: Chemical \& Pharmaceutical Bulletin 2011, 59, 1393. http://dx.doi.org/10.1248/cpb.59.1393

[20] Helaly F., El-Sawy S., Hashem A., Mourad R.: Egyptian Journal of Chemistry 2018, 61, 61. http://dx.doi.org/10.21608/EJCHEM.2018.2121.1170

[21] Shi L.S., Wang L.Y., Wang Y.N.: European Polymer Journal 2006, 42, 1625. http://dx.doi.org/10.1016/j.eurpolymj.2006.01.007

[22] Soliman H., Shattory Y.: Egyptian Journal of Chemistry 2017, 60, 591. http://dx.doi.org/10.21608/EJCHEM.2017.889.1041

[23] Wang H., Liu Y., Sun B. et al.: Advanced Materials Research 2013, 748, 16. http://dx.doi.org/10.4028/www.scientific.net/ AMR.748.16

[24] Das S., Mohanty S., Nayak S.: Journal of Inorganic and Organometalic Polymer Materials 2017, 27, 641. http://dx.doi.org/10.1007/s10904-017-0506-z

[25] Zhang Y., Maxted J., Barber A. et al.: Polymer Degradation and Stability 2013, 98, 527. http://dx.doi.org/10.1016/j.polymdegradstab.2012.12.003

[26] Gupta T., Adhikari B.: Thermochimica Acta 2003, 402, 169.

http://dx.doi.org/10.1016/S0040-6031(02)00571-3

[27] Beachell H.C., Son C.P.N.: Journal of Applied Polymer Science 1963, 7, 2217. http://dx.doi.org/10.1002/app.1963.070070621

[28] Zhang T., Wang L.: Materials Reports 2014, 28, 104.

Received 7 I 2020. 